\title{
Sediment replenishment as a measure to enhance river habitats in a residual flow reach downstream of a dam
}

\author{
S. Stähly \& A.J. Schleiss \\ École Polytechnique Fédérale de Lausanne (EPFL), Lausanne, Switzerland \\ M.J. Franca \\ IHE Delft Institute for Water Education \& Delft University of Technology, Delft, The Netherlands \\ C.T. Robinson \\ Swiss Federal Institute of Aquatic Science and Technology (EAWAG), Dübendorf, Switzerland
}

\begin{abstract}
Floodplains downstream of a dam, where the natural flow regime is replaced by a constant residual flow discharge, often lack sediment supply and periodic inundation due to the absence of natural flood events. In this study, a flood with a one-year return period was released from an upstream reservoir and combined with sediment replenishment. The aim was to enhance hydraulic habitat conditions in the Sarine river downstream of Rossens dam in Western Switzerland. A special configuration of sediment replenishment was applied. It consisted of four sediment deposits distributed as alternate bars along the river banks, a solution which was previously tested in the laboratory. The morphological evolution of the replenishment and of the downstream riverbed were surveyed including pre- and post-flood topography. The hydro-morphological index of diversity (HMID) was used to evaluate the quality of riverine habitats in the analyzed reach. It is based on the variability of flow depth and flow velocity. The combination of the artificial flood with sediment replenishment proved to be a robust measure to enhance sediment dynamics.
\end{abstract}

RÉSUMÉ: Les plaines inondables en aval d'un barrage, où le régime d‘écoulement naturel est remplacé par un écoulement résiduel constant, manquent souvent l'alimentation de sédiment et d'inondations périodiques à cause de l'absence des crues naturelles. Dans cette étude, une crue artificielle avec une période de retour d'un an a été relâché d'un réservoir en amont et combinée avec du réapprovisionnement des sédiments. L'objectif était d'améliorer les conditions des habitats hydrauliques dans la Sarine en aval du barrage de Rossens, en Suisse romande. Une configuration spéciale du réapprovisionnement des sédiments a été appliquée consistant en quatre dépôts de sédiments formés en barres alternées le long des rives du fleuve. Cette solution avait déjà été testée et optimisée en laboratoire. L'évolution morphologique de la reconstitution et du lit de la rivière en aval a été étudiée, y compris la topographie avant et après la crue. L'indice hydro-morphologique de la diversité (IHMD) a été utilisé pour évaluer la qualité des habitats riverains dans le tronçon analysé. Il est basé sur la variabilité de la profondeur et de la vitesse d'écoulement. La combinaison d'une crue artificielle et du réapprovisionnement des sédiments $s^{6}$ est révélée être une mesure robuste pour alimenter les rivières en sédiments et améliorer la dynamique sédimentaire.

\section{INTRODUCTION}

\subsection{Background}

Sediment dynamics are an often neglected but essential linkage in the nexus between waterfood-energy and ecosystems (Wohl et al., 2015). Flow and sediment dynamics are two 
interlinked key abiotic drivers in riverine ecosystems hosting a large variety of habitats. Water storage through dam construction in rivers are vital infrastructures to guarantee food and energy production (Schleiss, 2017), however these have a severe impact on both abiotic drivers. They regulate the flow and interrupt the longitudinal transport of sediment along the river bed. Deposited sediments in a reservoir cause the loss of storage capacity. On the other hand, a lack of sediment causes river incision downstream of the dam, streambank erosion, pauperization of morphology and loss of habitats and fluvial connectivity (Kondolf, 1997). In extreme cases, downstream sediment depletion can affect sub-surface waters. Different measures to mitigate the downstream lack of sediments are applied in practice such as flushing, sediment bypassing and artificial replenishment of sediments, although with limited results and viability. Including the sediment dynamics in catchment management contributes to socially and environmentally sustainable water, food, and energy security, contributing directly to Agenda 2030 of the United Nations in several of its targets (Nerini et al., 2018).

Flood pulses released intentionally by dam owners, typically through their bottom outlets, can be combined with sediment replenishment in downstream reaches to deal with the problem of sediment dynamics. Such reservoir flushing events in the case of a reservoir drawdown can have significant impact on water turbidity and fish in downstream reaches and in the reservoir itself; hence such operations need to be carefully planned and monitored (Grimardias et al., 2017). An experimental one-year return flood from pre-dam condition, combined with sediment replenishment, was tested downstream of Rossens dam on the river Sarine in Switzerland. Sediment replenishment, analogous with one tested in laboratory, consisted of four deposits alternately distributed along both banks of the river (Battisacco et al., 2016). According to the laboratory study, sediment brought in the river with this configuration settles in periodic clusters of sediment on the river bed. This may enhance enhancing habitat diversity in a reach. In this conference paper, the sediment replenishment combined with an artificial flood event in the Sarine river in western Switzerland was quantitatively investigated with an index that represents hydraulic habitat diversity.

\subsection{Study river: Sarine}

The study took place at the Sarine river in the Canton Fribourg in western Switzerland. Its origin is at the Sanetsch at $2252 \mathrm{~m}$ a.s.l. and drains into the Aare, a tributary of the Rhine. Along its $125 \mathrm{~km}$, multiple reservoirs for hydropower production were built, resulting in a regulated flow regime. In Rossens, a 83-m high arch dam forms the over 13-km long Lac de la Gruyère, which has a volume of 200 million $\mathrm{m}^{3}$. Being located in a pre-alpine valley, the lake is relatively long and the sediment continuum is completely interrupted by the dam. Since construction in 1948, a residual discharge of $2.5-3.5 \mathrm{~m}^{3} / \mathrm{s}$ has been released at Rossens dam. This is the only discharge in the $13.4 \mathrm{~km}$ long bed-rock alluvial reach with an average slope of $0.3 \%$ between the dam and the powerhouse in Hauterive (see Figure 1). In Hauterive, up to $76 \mathrm{~m}^{3} / \mathrm{s}$ re-enter the Sarine during electricity production causing downstream hydropeaking. The tributary La Gérine supplies the hydropeaking part of the Sarine with sediment, before the Sarine enters Lac de Pérolle, impounded by Maigrauge dam. Daily and weekly flow patterns of the two reaches are given in Figure 2. The dam creation and operation had a severe impact on the sediment dynamics of the Sarine river in the past decades. The sediment interruption and monotonous flow led to river incision. This allowed vegetation to colonize gravel bars. The absence of regular inundation and habitat turnover allowed hardwood vegetation to grow on former gravel bars. The active river width therefore has drastically decreased since 1948 (see Figure 3). The Sarine floodplain lies in an incised 100-m wide canyon surrounded by agricultural terrain and villages. Therefore, human-built structures in the floodplain are limited to some gravel roads, a handful of buildings, and hiking paths besides the hydropower-related structures.

The experiment with the artificial flood was a collaborative research effort led by the authorities of the Canton with the participation of different institutions (Zurich University of Applied Sciences, Swiss Federal Institute of Aquatic Sciences and Technology, University of 


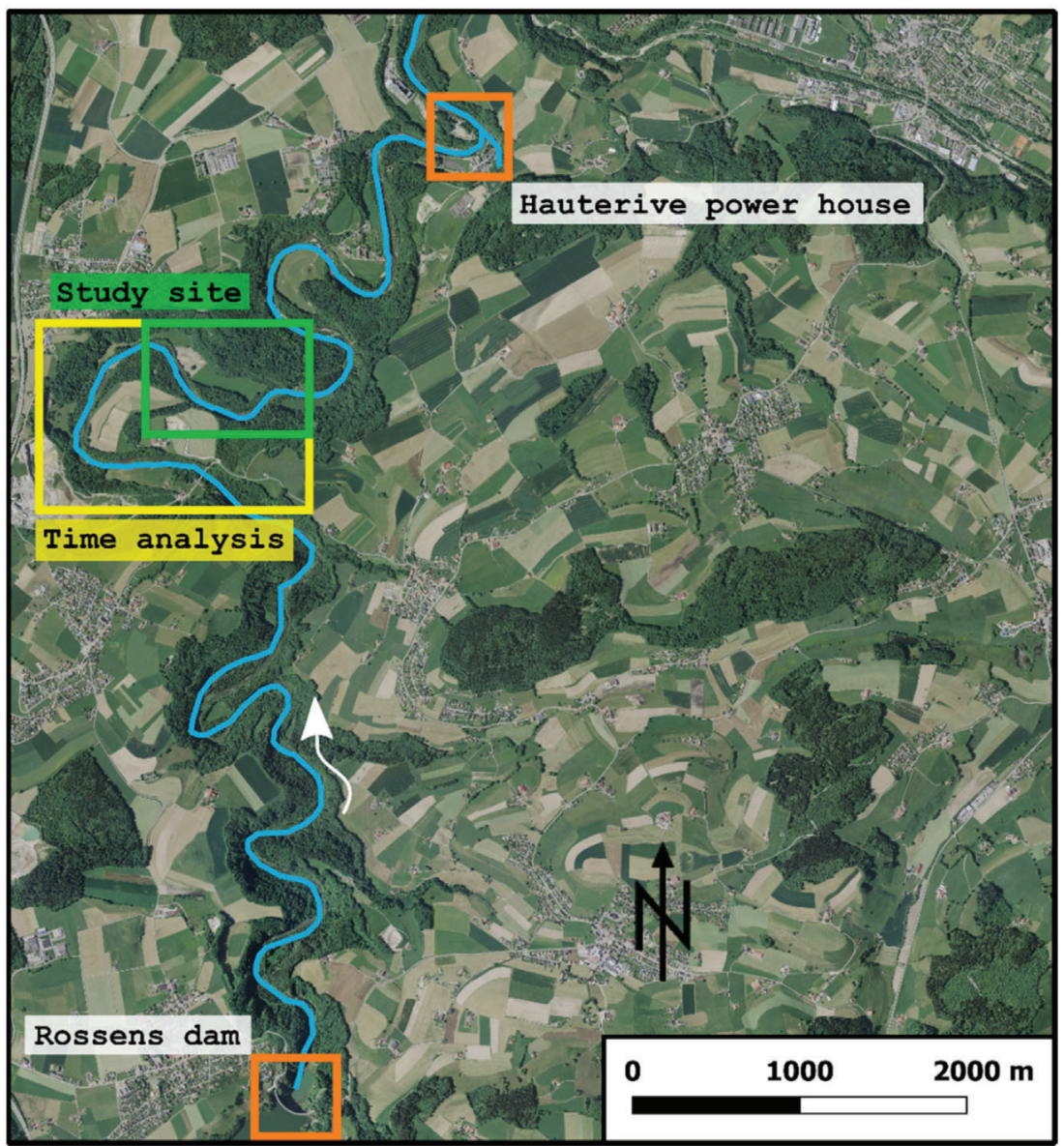

Figure 1. Overview of the Sarine river between Rossens dam and the power house in Hauterive. Geodata (c) Swisstopo.

Zurich and the École Polytechnique Fédérale de Lausanne), and in collaboration with the dam owners (Groupe e) and consulting engineers (Hydrique, Pronat). The aim of the project was to simulate a dynamic flow and sediment regime in the Sarine floodplain that has been absent since the construction of Rossens dam.

\section{METHODS}

\subsection{The artificial flood and the replenishment of sediments}

Nine kilometers downstream of Rossens dam, a total volume of $1000 \mathrm{~m}^{3}$ sediment was added to the Sarine. The material was split in four deposits of the same size placed as alternate bars similar to the configuration tested in the laboratory experiments of Battisacco (2016). The deposits were about $7 \mathrm{~m}$ wide (river width $30 \mathrm{~m}$ ), $22 \mathrm{~m}$ long and about $1.5 \mathrm{~m}$ high. The exact location of the sediment replenishment is noted in Figure 6, the coordinates correspond to $46^{\circ}$ $45^{\prime} 29.21^{\prime \prime} \mathrm{N}, 7^{\circ} 06^{\prime} 11.47^{\prime \prime} \mathrm{E}$. The sediment material was excavated from the adjacent floodplain, sorting or washing of the material did not occur. The replenished material had the same characteristic diameters as the river bed, with $\mathrm{d}_{\mathrm{m}}=57 \mathrm{~mm}$ and $\mathrm{a} \mathrm{d}_{90}=113 \mathrm{~mm}$. The characteristic diameters were calculated by line sampling and photo sieving (Stähly et al. 2017). 


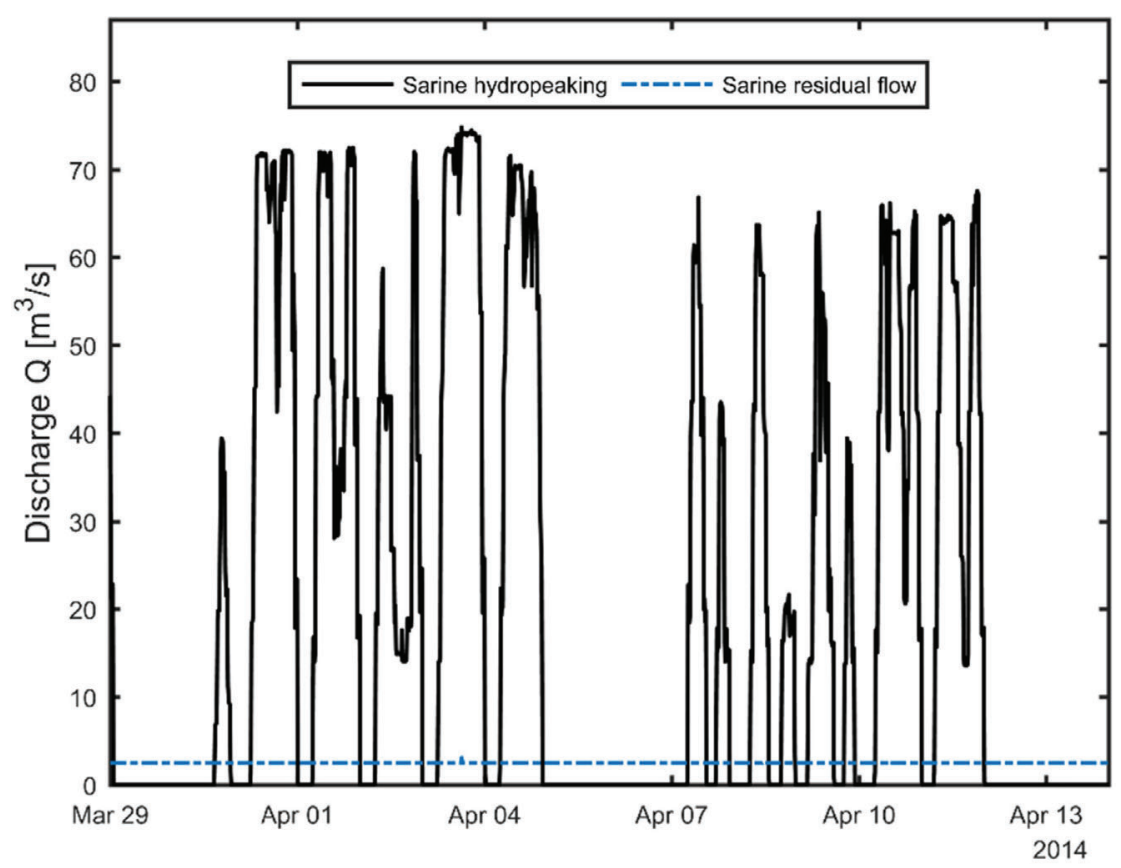

Figure 2. Typical daily and weekly flow patterns in March and April 2014 in the hydropeaking and residual flow reach of the Sarine. Flow data from the dam operator company Groupe e.

The flood pulse released from Rossens dam corresponded to a return period of one year from pre-dam conditions and had a peak discharge of $195 \mathrm{~m}^{3} / \mathrm{s}$. Because of polluted areas near the floodplain, the hydrograph could not be designed with a higher magnitude. This restriction was counteracted with the shape of the hydrograph. Peak discharge was kept for two hours then slightly decreased and held for another 3 hours (see Figures 4 and 5). The whole artificial flood event lasted from $05 \mathrm{~h} 00$ on 24 September until 08h30 on 25 September 2016.

\subsection{Hydro-Morphological Index of Diversity (HMID) to evaluate hydraulic habitat diversity}

Changes in hydraulic habitat diversity were quantified using the hydro-morphological index of diversity (HMID, Gostner, 2012; Gostner et al., 2012). The HMID is based on the hypotheses that the structural diversity of a river reach can be characterized by the variation of flow depth and velocity present in a river reach. To have a comparable measure, the standard deviations are normalized by the mean value of flow depth and flow velocity (Equation 1).

$$
H M I D=\prod_{i}\left(1+C V_{i}\right)^{2}=\left(1+\frac{\sigma_{h}}{\mu_{h}}\right)^{2} \cdot\left(1+\frac{\sigma_{v}}{\mu_{v}}\right)^{2}
$$

where $C V=$ coefficient of variation of variable $i ; \mu_{h}$ and $\mu_{v}=$ mean value of flow depth $(h)$ and velocity $(v)$, respectively; and $\sigma_{h}$ and $\sigma_{v}$ are the corresponding standard deviations.

Generally, HMID-values vary between 1 and 15, depending on river morphology and discharge. According to Gostner et al. (2012), HMID values can be assigned to three different categories:

$-1<$ HMID < 5: Channelized/heavily altered

- $5<$ HMID < 9: Limited variability

- HMID > 9: Fully developed spatial dynamics 

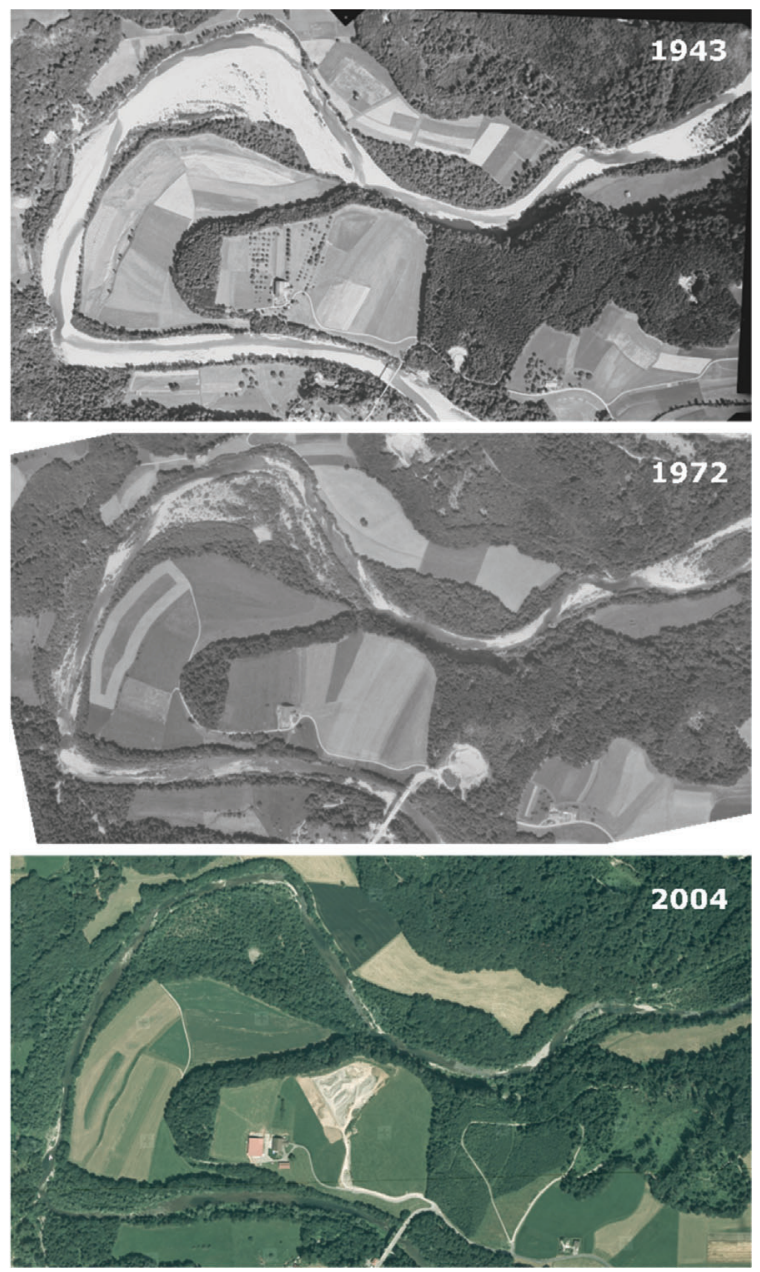

Figure 3. Decrease in active river surface in the Sarine residual flow reach due to dam construction in 1948. Flow direction is from the bottom to the top. The exact location of this area of the Sarine catchment is noted in Figure 1. Geodata (C) Swisstopo.

In total, a 850-m long reach was analyzed with the HMID. In this sector, nine equally spaced cross-sections were defined. The spacing of $95 \mathrm{~m}$ corresponded to about three times the wetted river width. The river was crossed on each cross-section and every meter, flow depth and flow velocity were measured. Flow velocity was measured at $60 \%$ of the flow depth corresponding to the depth-averaged flow velocity in a water column. Flow velocity was measured across cross-sections with a Handheld-ADV (FlowTracker from SonTek). The exact locations were recorded with a differential GPS, allowing to measure at the same location again after the flood event as before. In total, 207 measurement points were recorded prior and 192 after the artificial flood. This difference can be explained by the different discharges at the moment of measurement. The residual discharge prior the event was $3.5 \mathrm{~m}^{3} / \mathrm{s}$ and afterwards $2.5 \mathrm{~m}^{3} / \mathrm{s}$, causing a change in wetted surface.

\subsection{Radio frequency identification technique}

In order to distinguish the area influenced by the sediment replenishment, 489 stones with a mean diameter of $57 \mathrm{~mm}$ and $113 \mathrm{~mm}$ (corresponding to $\mathrm{d}_{\mathrm{m}}$ and $\mathrm{d}_{90}$ ) were equipped with RFID 


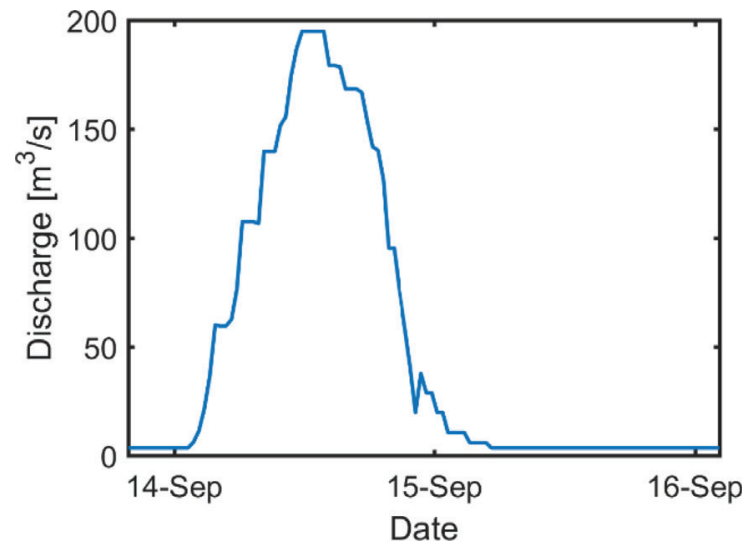

Figure 4. Hydrograph of the flood pulse. Peak discharge of this one year flood was limited by restrictions in the flooding perimeter. The flood lasted more than 24 hours starting from 14 September 2016 at 05h00 to 15 September 08 h30. Discharge data from the dam operator company Groupe e.

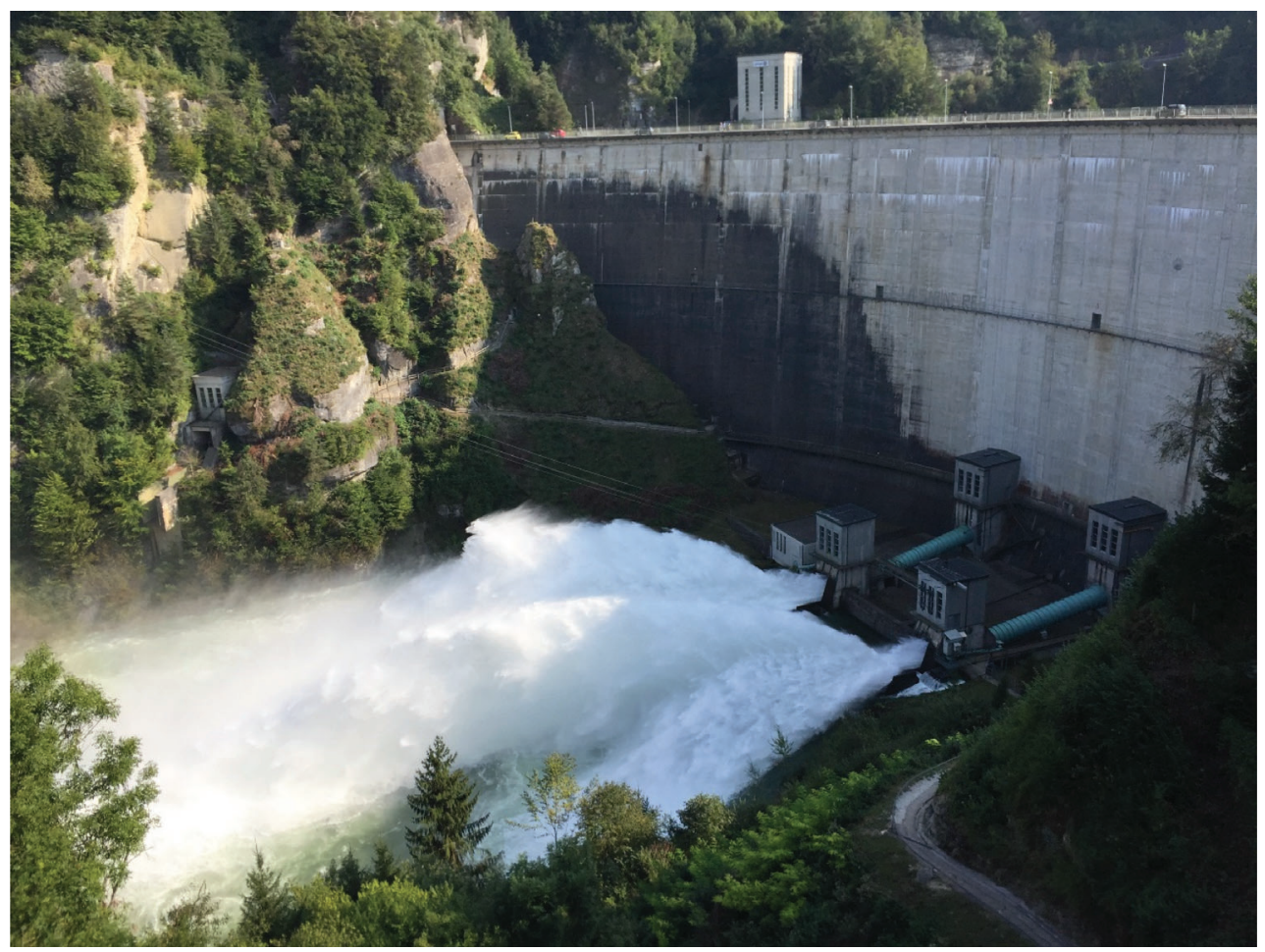

Figure 5. Rossens dam on 14 September 2016 during the artificial flood event. Image C Severin Stähly

PIT tags (Passive Integrated Transponder). This radio frequency identification technique allows the identification of a tagged stone when it is within an electromagnetic field (Schneider et al, 2010; Arnaud et al., 2015). The stones were collected in the Sarine river, drilled, equipped with a tag and sealed with silicon before being placed equally distributed in the different deposits. After the flood event, the tagged stones were searched with a mobile antenna, allowing the determination of the perimeter in which the replenishment had an influence of the river. 


\section{RESULTS}

\subsection{Stone recovery}

The replenished sediment was only partially eroded. From the 489 stones, 277 were found in the river after the flood event. The largest transported distance corresponded to $286 \mathrm{~m}$. The recovery places of the tagged stones allowed to draw the replenishment impact perimeter in the river reach (see Figure 6). Cross-sections CS 2, CS 3 and CS 4 lie within the replenishment impact zone, resulting in the calculation of two HMID values, one with the data of the cross-sections mentioned, and a second one with the data of the cross-sections CS 1 and CS 5-9. This allows to distinguish the impact of the release of the artificial flood separated from the combination of the artificial flood with the sediment replenishment.

\subsection{Change in hydraulic habitat diversity}

The HMID obtained from the data of the impact perimeter, increased from 5.6 to 7.7, corresponding to an improvement of $36 \%$. The HMID outside of the perimeter increased also but only by $18 \%$ (see Tab. 1). In both river reaches, the mean flow velocity and depth decreased. In the reach that lies within the perimeter of the sediment replenishment, the standard deviation of both measures increased as well. In the reach that lies outside of the replenishment perimeter, the standard deviation of the flow depth increase slightly, while the standard deviation of the flow velocity decrease.

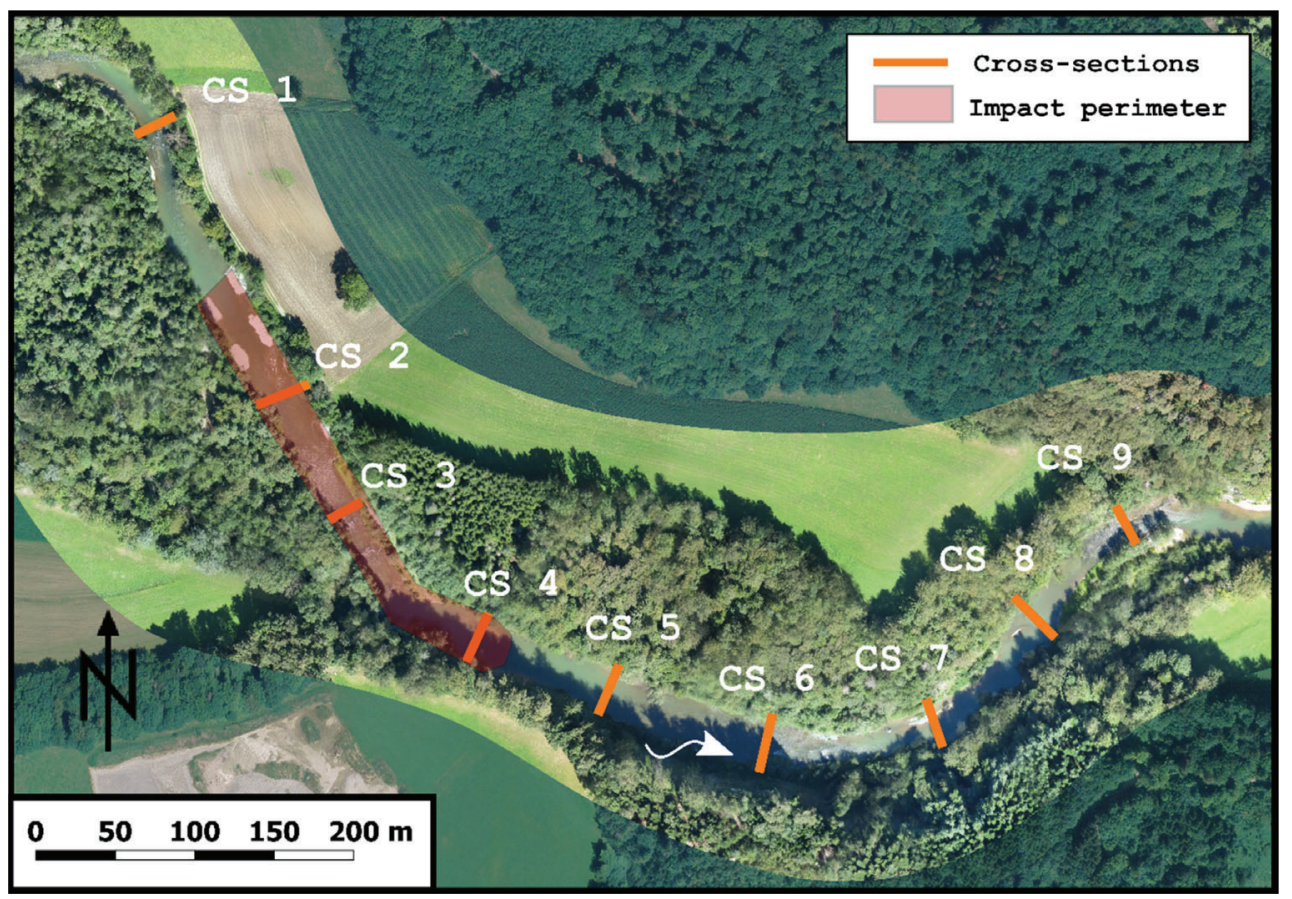

Figure 6. The nine cross-sections at which flow depths and velocities were measured before and after the artificial flood event. The impact perimeter, corresponding to the area where the tagged stones were recovered, is marked in red. Between cross-section CS 1 and CS 2, the $1000 \mathrm{~m}^{3}$ replenished sediment, divided in four deposits, is visible as they were placed prior to the flood event. Background image (C) Research group Ecohydrology, ZHAW. 
Table 1. HMID values before (prior) and after (post) the flood event for the reach inside the perimeter of the sediment replenishment (HMID impact $_{\text {) }}$ and the reach outside (HMID outside).

\begin{tabular}{|c|c|c|c|c|c|}
\hline \multirow[b]{2}{*}{ Setting } & & \multicolumn{2}{|c|}{ HMID $_{\text {impact }}$} & \multicolumn{2}{|c|}{ HMID outside } \\
\hline & & PRIOR & POST & PRIOR & POST \\
\hline Data points & {$[-]$} & 71 & 58 & 136 & 134 \\
\hline$\mu_{h}$ & {$[\mathrm{~m}]$} & 0.40 & 0.38 & 0.55 & 0.49 \\
\hline$\sigma_{h}$ & {$[\mathrm{~m}]$} & 0.18 & 0.23 & 0.33 & 0.34 \\
\hline$\mu_{v}$ & {$\left[\mathrm{~ms}^{-1}\right]$} & 0.45 & 0.42 & 0.42 & 0.38 \\
\hline$\sigma_{h}$ & {$\left[\mathrm{~ms}^{-1}\right]$} & 0.28 & 0.31 & 0.37 & 0.35 \\
\hline HMID & {$[-]$} & 5.6 & 7.7 & 9.0 & 10.6 \\
\hline Variation & {$[\%]$} & & +36 & & +18 \\
\hline
\end{tabular}

\section{CONCLUSIONS}

The release of an artificial flood combined with sediment replenishment significantly increased the hydraulic habitat diversity in the Sarine river downstream of Rossens dam. Furthermore, the release of the artificial flood lead to an increase in HMID outside of the sediment replenishment perimeter. The enhancement achieved with the combination of flood release with sediment replenishment was substantial (36\% versus $18 \%$ outside of the perimeter). In contrast, a sole release of a flood pulse in the absence of sediment replenishment likely would lead to a wash-out of sediment in the bedrock-alluvial Sarine river and accelerate bed incision if such an event is repeatedly operated. Thus, sediment replenishment following this first positive restoration experience should be placed close to the dam to supply the entire river reach with sediment. Depending on target fish or macro-invertebrate species in the river or restoration, it could be beneficial if the grain sizes of the replenished sediment correspond to the needs of the target species. The present results encourage further similar experiments and may spark the discussion of further possibilities for the definition of environmental flows and proper sediment management in river reaches impacted by dams. The biological survey that was performed parallel to this study also revealed positive first effects of the flood in the Sarine (Döring et al., 2017).

\section{ACKNOWLEDGEMENT}

The authors express their gratitude to Jonas Durand-Gasselin, Anthony Maître, Elena Battisacco, Kevin Gianom, Matthias Thalmann and Diego Tonolla for their help during the flood event. Further thanks goes to the Cantonal authorities of Fribourg, the dam operator Groupe e and the Brodard Services Hauteville for their collaboration and the placement of the sediment replenishment. This research is part of the National Research Programme 70 "Energy Turnaround" (NRP 70, www.nrp70.ch) of the Swiss National Science Foundation (SNSF, Project No. 153972). The first author additionally is supported by the Swiss Federal Office of Energy (SFOE, Project No. 501673-01).

\section{REFERENCES}

Arnaud, F., Piégay, H., Vaudor, L., Bultingaire, L. \& Fantino, G. 2015. Technical specifications of lowfrequency radio identification bedload tracking from field experiments: Differences in antennas, tags and operators. Geomorphology 238: 37-46.

Battisacco, E. 2016. Replenishment of sediment downstream of dams: erosion and transport processes. In Anton Schleiss (ed.), Communication No. 67 of Laboratory of Hydraulic Constructions ( LCH). PhD thesis No. 7239, École Polytechnique Fédérale de Lausanne, Lausanne, Switzerland. 
Battisacco, E., Franca, M.J. \& Schleiss, A.J. 2016. Sediment replenishment: Influence of the geometrical configuration on the morphological evolution of channel-bed. Water Resources Research 52: 8879-8894.

Döring, M., Tonolla, D., Robinson, C.T., Schleiss, A.J., Stähly, S., Gufler, C., Geilhausen, M. \& Di Cugno, N. 2018. Künstliches Hochwasser an der Saane-Eine Massnahme zum nachhaltigen Auenmanagement. Wasser Energie Luft, 110: 119-127.

Gostner, W. 2012. The Hydro-Morphological Index of Diversity: a planning tool for river restoration projects. In Anton Schleiss (ed.), Communication No. 51 of Laboratory of Hydraulic Constructions $(\mathrm{LCH})$. PhD thesis No. 5408, École Polytechnique Fédérale de Lausanne, Lausanne, Switzerland.

Gostner, W., Alp, M., Schleiss, A.J. \& Robinson, C.T. 2013. The hydro-morphological index of diversity: A tool for describing habitat heterogeneity in river engineering projects. Hydrobiologia 712: 43-60.

Grimardias, D., Guillard, J. \& Cattanéo, F. 2017. Drawdown flushing of a hydroelectric reservoir on the Rhône River: Impacts on the fish community and implications for the sediment management. Journal of Environmental Management 197: 239-249.

Kondolf, G.M. 1997. PROFILE: hungry water: effects of dams and gravel mining on river channels. Environmental management 21(4): 533-551.

Nerini, F.F., Tomei, J., To, L.S., Bisaga, I., Parikh, P., Black, M., Borrion, A., Spataru, C., Broton, V.C., Anandarajah, G., Milligan, B. \& Mulugetta, Y. 2018. Mapping synergies and trade-offs between energy and the Sustainable Development Goals. Nature. Energy 3: 10-15.

Schneider, J., Hegglin, R., Meier, S., Turowski, J.M., Nitsche, M., \& Rickenmann, D. 2010. Studying sediment transport in mountain rivers by mobile and stationary RFID antennas. In Dittrich, Andreas; Koll, Katinka; Aberle, Jochen \& Geisenhainer, Peter (ed.), River Flow 2010, Karlsruhe, 8.-10. June. Karlsruhe: Germany. 1723-1730.

Stähly, S., Friedrich, H. \& Detert, M. 2017. Size Ratio of Fluvial Grains' Intermediate Axes Assessed by Image Processing and Square-Hole Sieving. Journal of Hydraulic Engineering 143: 6017005.

Wohl, E., Bledsoe, B.P., Jacobson, R.B., Poff, N.L., Rathburn, S.L., Walters, D.M., \& Wilcox, A.C. 2015. The natural sediment regime in rivers: Broadening the foundation for ecosystem management. BioScience 65(4): 358-371. 